\title{
1. Setting the scene: law and persuasion
}

\subsection{INTRODUCTION}

In early 1993, I was talking to Jeremy Pope, the outgoing Director of the Legal and Constitutional Affairs Division at the Commonwealth Secretariat, about his future plans. In my experience, international public officials at this level of seniority normally do one of three things: move into a similar position in another international organization; return to their home country to pursue a political career; or retire on a very healthy pension. To my surprise (perhaps astonishment is a better description), Jeremy told me that he was moving to Berlin to set up an anti-corruption non-governmental organization. Given that corruption has been a fact of life for centuries with efforts to combat it seemingly having minimal success, I think my response was entirely understandable. Certainly at that time there were no international or regional anti-corruption instruments, very few countries had effective anti-corruption/bribery or antimoney laundering legislation in place whilst some heads of state and other senior public officials were almost routinely looting state assets and laundering the proceeds through Western financial institutions. Similarly, the bribery of foreign public officials by the private sector in order to obtain or retain business was commonplace with some countries even making such payments tax deductible.

Since then, so much has changed. Jeremy Pope duly went off to Berlin and there co-founded Transparency International which has proved one of the catalysts for the development of a plethora of civil society organizations dedicated to combating corruption. ${ }^{1}$ In addition, international efforts to take

1 During the writing of this book, I received news from New Zealand that Jeremy Pope had died. He was a truly great servant to the cause of good governance/just and honest government in the Commonwealth and beyond and as Frederik Galtung has rightly put it, Jeremy was 'one of the pillars, greatest innovators and forces for good in the international integrity and anti-corruption movements'. See 'Jeremy Pope: In Memoriam' <http://www.integrityaction.org/ joy/jeremy-pope-\%E2\%80\%93-memoriam> accessed 1 July 2013. 
action against corruption have resulted in the development of a series of regional anti-corruption instruments and initiatives, which culminated with the coming into force of the United Nations Convention Against Corruption (UNCAC) in 2005. These place numerous good governance obligations on states globally and it is noteworthy that the African Union and African states were actively involved in many of these developments.

\subsection{THE MAIN ARGUMENTS}

Whilst we have certainly come a long way in a short space of time, the challenge remains of ensuring that these obligations are fulfilled in practice. This book seeks to make a contribution to this goal from the African perspective and is based on three premises.

Firstly, that the development and maintenance of good governance laws and institutions are the foundation upon which African states can and must seek to enhance integrity and combat corruption. This is not simply a matter of pious hope for almost all African states are parties to both the AU Convention on Preventing and Combating Corruption (the AU Convention) and UNCAC whilst all the states of the Southern African Development Community (SADC) are parties to the SADC Protocol Against Corruption (the SADC Protocol). These require State Parties to develop four good governance/anti-corruption 'pillars':

1. Effective corruption preventive measures;

2. Strategies to facilitate the investigation and criminalization of corruption and related offences;

3. Effective international cooperation in the investigation and prosecution of corruption and related offences; and

4. Strategies for recovering the proceeds of corruption.

Fundamental to ensuring the effectiveness of these pillars is the requirement that states have in place a wide range of good governance laws, institutions and procedures. The emphasis on good governance is further highlighted by the fact that 15 states have also ratified the African Charter on Democracy, Elections and Governance, an objective of which is to 'Nurture, support and consolidate good governance by promoting democratic culture and practice [and] building and strengthening governance institutions... '. ${ }^{2}$ In addition,

2 This was adopted by the Eighth Ordinary Session of the AU Assembly on 30 January 2007 and came into force on 15 February 2012 after its ratification by Cameroon. 
the Recommendations introduced in 2012 by the Financial Action Task Force on combating money laundering 3 place a requirement on all African states to enact additional 'good governance' laws and regulations with their implementation being overseen by the three African FATF-style regional bodies. ${ }^{4}$

In essence, African states have committed themselves to establishing good governance laws and institutions as a means of enhancing integrity and combating corruption and these form the basis for the discussion in this book.

Secondly, that the art of persuasion is fundamental to developing the necessary political will to make the legal strategies 'work'. Whether there is any real commitment on the part of those in political power to put the anti-corruption/good governance strategies into practice is often debateable. Thus analysing how States might be 'persuaded' to do so and how effective such provisions are in practice will help determine whether such initiatives are of any real value. This book analyses a variety of 'persuasive' techniques that are being adopted to achieve this goal. Of course, the art of persuasion is not limited to the public sector for it is the private sector that also bears responsibility for 'bad governance', for example through the bribery of African public officials in order to obtain or retain business. Here again, the challenge is to explore ways in which even the most powerful corporations worldwide can be 'persuaded' to develop and maintain good governance in their dealings with African states.

Thirdly, that supporting good governance and combating corruption is not just an African concern but is also a global issue. Given the sometimes disastrous outside attempts to address Africa's problems there is some merit in the argument that governance and democratic reforms in Africa must be, and be seen to be, undertaken by Africans for Africans. Yet combating corruption also includes a transnational dimension. For example, the looting of state assets by senior public officials (known as politically exposed persons (PEPs)) and their families is often facilitated by banks, other financial institutions and 'gate-keepers' 5 around the

3 FATF International Standards on Combating Money Laundering and the Financing of Terrorism \& Proliferation - the FATF Recommendations 2012 Paris.

4 The Eastern and Southern African Anti-Money Laundering Group (ESAAMLG), the Inter-Governmental Action Group Against Money Laundering in West Africa (GIABA) and the Middle East and North Africa Financial Action Task Force (MENAFATF). See Chapter 10 for details.

5 Such as legal professionals and accountants. 
world. How else could Abacha, Mobutu and Mubarak, to name but a few, steal enormous sums of money from their countries, move them abroad and launder them through off-shore 'secrecy' jurisdictions? It means that victim African states require global cooperation and support both in seeking to prevent the laundering of the proceeds of corruption and also in their recovery and return no matter where in the world they are located. ${ }^{6}$

\subsection{THE ARRANGEMENT OF THE BOOK}

The arrangement of the book essentially follows the four good governance/anti-corruption pillars although there is often some overlap between topics. Chapter 2 explores the laws and governance issues that support integrity and the combating of corruption. It explains the scope of 'corruption' for the purposes of the book and emphasizes that there is no satisfactory 'legal' definition of the word. It then focuses on the transnational initiatives and in particular on the scope and contents of the African Union Convention on Preventing and Combating Corruption and the United Nations Convention Against Corruption. This is followed by an examination of the key good governance building blocks at the national level: that is a popular, effective and durable constitution and an effective statutory and regulatory system. Given that it is unrealistic to expect that every state will constantly enjoy the necessary political will to support good governance, the chapter then explores the different 'categories' of political will and highlights the importance of 'seizing the moment' and taking action when the political will exists.

As regards the prevention pillar, Chapters 3 and 4 focus on maintaining integrity in the public service. Chapter 3 explores some of the strategies that States must employ to help promote and maintain 'integrity, honesty and responsibility among its public officials' ${ }^{7}$ Section 1 examines the development and operation of codes of conduct, asset and income declarations and strategies for addressing conflicts of interest. Section 2 then considers some of the challenges associated with money and politics including the financing of election campaigns and the seemingly intractable problems of how ministers and parliamentarians can cope with the financial and other demands of family, friends and constituents. Finally, Section 3 explores the challenges for maintaining and enhancing integrity

6 This is through the development of international cooperation such as mutual legal assistance regimes: see Chapter 10, p. 303.

7 See Article 8(1) of UNCAC. 
in public sector finances. What happens when things go wrong and the good governance/integrity safeguards break down is explored in Chapter 4. In particular it considers the use and abuse of constitutional immunities and parliamentary privilege and then explores the combating of the misuse of public office through the use of both criminal and civil law mechanisms.

The fundamental values of a nation are enshrined in its national constitution and given that 'corruption and maladministration are inconsistent with' those values, ${ }^{8}$ it plays a key role in upholding good governance and accountability. Chapter 5 explores this role in several ways. Section 1 provides an overview of the development of constitutions in Africa and the challenges of making them instruments of good governance. Section 2 then considers the connection between constitutional rights and corruption. This reflects the fact that in recent years, attention has increasingly turned towards utilizing constitutional/human rights protection and enforcement mechanisms and institutions through which to combat corruption. Section 3 then explores the contribution that constitutional oversight bodies can make in combating corruption whilst Section 4 reviews the tensions between the enjoyment of constitutional rights and the development of effective anti-corruption strategies.

Issues concerning the second good governance/anti-corruption pillar, namely the investigation and prosecution of corruption-related offences, are considered in Chapters 6,7 and 8.9 Both the AU Convention and UNCAC are largely devoted to these areas and this emphasis reflects the popular view that the most effective way of combating corruption is through 'forceful persuasion' that is the use of the criminal law and the imposition of 'effective, proportionate and dissuasive' sanctions. Whether this is a realistic expectation is a key issue here. Chapter 6 focuses firstly, on the practical and political challenges to the effective investigation and prosecution of corruption-related offences. It then examines the scope of the offences themselves and highlights the fact that rather than seeking to prosecute 'high risk' offences such as bribery, prosecutors have a range of alternative charges, which may well offer a more realistic prospect of conviction. The final section considers the somewhat controversial area of doing 'deals' with PEPs and/or their families, which involve the

8 Chaskalson, P in South African Association of Personal Injury Lawyers $v$ Heath [2000] ZACC 22; 2001 (1) BCLR 77 [4] (Constitutional Court of South Africa).

9 Given the wide range of offences covered in the AU Convention and UNCAC, the term 'corruption-related offences' is preferred to 'corruption offences' throughout this book. 
dropping of criminal investigations/charges in exchange for the return of looted state assets. In view of the challenges to the investigation and prosecution of corruption, many African states have established anticorruption bodies (ACB), often in the form of an 'independent' anticorruption commission. Chapter 7 explores the contribution that such bodies can make, in practice, to combating corruption and enhancing good governance and integrity by focusing on two issues. Firstly whether there is the need for a separate anti-corruption commission at all and secondly, if there is, what mandate it should enjoy and what building blocks are required to enable it to maintain its independence and effectiveness. Chapter 8 then considers the challenges to upholding judicial independence and integrity whilst at the same time providing for judicial accountability. It also explores whether, in the face of allegations of judicial corruption, there is a need for states to establish specialized anti-corruption courts.

The prevention and criminalization pillars also apply to the private sector and this aspect is explored in Chapter 9. Effective work in this area is crucial in that combating corruption and enhancing good governance are neither the sole preserve of the public sector nor necessarily simply national issues. Today the private sector wields immense economic power and political influence both nationally and internationally and it is those sectors where the State and the private sector interact and intersect that are often characterized by corrupt practices. Yet given their economic and political power, together with the often strong political support from their 'home' states, 'persuading' (however reluctantly) the private sector, including even the most powerful multi-national corporate entities to act with integrity and to take appropriate measures to combat corruption in their business activities is extremely challenging. Here the chapter reviews a series of strategies that suggest that some progress can be, and is being, made in this regard through the use of 'gentle persuasion', 'forceful persuasion' and 'persuasive threats'.

The final two pillars, that is international cooperation and asset recovery, are considered in Chapters 10 and 11. Chapter 10 analyses the challenges faced by African States in seeking to combat the laundering of the proceeds of corruption, particularly where this involves a transnational element. ${ }^{10}$ Section 1 provides a general overview of the money laundering process itself but focuses primarily on its special connection

10 State Parties to both the AU Convention and UNCAC are required to establish the laundering of the proceeds of corruption as criminal offences: see p. 276 below. 
with corruption and how PEPs can 'control the controls' and thus provide themselves with unique money laundering opportunities. Section 2 reviews the development of anti-money laundering strategies through the work of the Financial Action Task Force (FATF) and the three African FATF-style regional bodies and considers, in particular, strategies for addressing the problems posed by PEPs. International cooperation is the third of the four anti-corruption pillars and Chapter 11 considers how to put into effect Article 18(1) of the AU Convention which requires African states to 'provide each other with the greatest possible technical cooperation and assistance in dealing immediately with requests from authorities that are empowered by virtue of their national laws to prevent, detect, investigate and punish acts of corruption and related offences' ${ }^{11}$ The chapter then provides an overview of the principles relating to the fourth and final anti-corruption pillar: that of asset recovery itself.

Chapter 12 then provides some final thoughts on making the anticorruption/good governance initiatives more effective through the 'art of persuasion': that is how to persuade reluctant states and the private sector to take their good governance and anti-corruption commitments and responsibilities seriously.

\subsection{THE ORGANIZATION AND SCOPE OF THE BOOK}

The organization of a book of this nature has posed something of a challenge, as there are frequent overlaps between issues. Thus it is not always obvious as to where a particular section 'belongs' and much is down to a personal preference. For example, some of the obligations placed on State Parties by the AU Convention and UNCAC to develop effective anti-corruption strategies inevitably affect the enjoyment of the constitutional right to a fair trial. This would suggest that the discussion of the issue would fit neatly in Chapter 6 which deals with the challenges of prosecuting corruption-related cases. However, I decided to develop a separate section in Chapter 5 which addresses the complex and sometimes controversial issue of 'Resolving tensions between the enjoyment of constitutional rights and the development of anti-corruption strategies'.

The book draws on the laws and experiences of a wide range of African states. However while the provisions of the AU Convention and UNCAC apply to all states whatever their individual legal system, much of the discussion on the more technical legal issues is from a common

11 FATF Recommendation 37 also contains detailed provisions: see p. 311 below. 
law perspective: for example the discussion on the complexities of the hearsay rule in criminal cases. However, it is hoped that it provides a 'holistic' perspective as to the legal approaches to combating corruption through good governance and integrity mechanisms.

The book also provides a series of case studies. Some illustrate the many success stories emanating from the continent, such as the determination of the government of Lesotho to prosecute those foreign companies responsible for paying bribes to obtain contracts on the Lesotho Highlands Water project. ${ }^{12}$ Others highlight some of the very real practical challenges to making good governance/anti-corruption strategies 'work', such as the Anglo Leasing affair in Kenya. ${ }^{13}$

Of course the book cannot, and does not seek to, provide a comprehensive analysis of every relevant issue or topic nor is it feasible (or necessary) to explore every possible example or initiative, particularly where new material is constantly becoming available. I have therefore tried to cover relevant materials available to me up to 1 July 2013 but many readers will undoubtedly want to add their own ideas and experiences and country-specific examples.

12 See p. 310.

$13 \quad$ See p. 313. 